\title{
Diagnoses of two new species of Parosphromenus (Teleostei: Osphronemidae) from Bangka Island and Kalimantan, Indonesia
}

\author{
WENTIAN SHI ${ }^{1,2}$, SHUJIE GUO ${ }^{1,5}$, HARYONO HARYONO 3 , \\ YIJIANG $\mathrm{HONG}^{1,4,6^{*}} \&$ WANCHANG ZHANG Z $^{1,4,7^{*}}$ \\ ${ }^{1}$ School of Life Sciences, Nanchang University, Nanchang 330031, China \\ ${ }^{2}$ Faculty of Philosophy, University of Tübingen, Tübingen 72074, Germany \\ "=wtshi.pku@gmail.com; • ittps://orcid.org/0000-0003-0130-7963 \\ ${ }^{3}$ Research Centre for Biology, Indonesian Institute of Sciences, Bogor 16911, Indonesia \\ ”ikharyono@yahoo.com; @ https://orcid.org/0000-0002-5143-6790 \\ ${ }^{4}$ Key Lab of Aquatic Resources and Utilization, Nanchang University, Nanchang 330031, China \\ ${ }^{5}$ ○ https://orcid.org/0000-0002-4178-0547 \\ 6"=yjhong2008@163.com; - i https://orcid.org/0000-0002-1180-5512 \\ ${ }^{7}$ !"wanchangzhang@hotmail.com; @ https://orcid.org/0000-0003-1040-2516 \\ ${ }^{*}$ Corresponding authors
}

\begin{abstract}
We describe two new species of Parosphromenus from Indonesia based on morphological and molecular diagnoses. Parosphromenus juelinae, sp. nov., occurs on Bangka Island. Its unpaired fin coloration is similar to that of $P$. deissneri, but it differs from the latter in having a rounded caudal fin with a non-filamentous branched median ray and a smaller anal fin. Although the new species has the same caudal fin structure as $P$. bintan, it can be distinguished from the latter by its distinct unpaired fin coloration and the intense red color on the body flanks. Parosphromenus kishii, sp. nov., is found only in a single river system in Kalimantan Tengah. It is distinguished from all other congeners by the unique coloration of its caudal fin. A phylogenetic tree based on the cytochrome b (cytb) gene indicates that the two new species are distinct monophyletic groups constituting distinct phylogenetic branches from their congeners. Cytochrome b Genetic distances between Parosphromenus juelinae, sp. nov., and Parosphromenus kishii, sp. nov., and the other taxa in the phylogenetic tree range from $2.44 \%$ to $19.52 \%$ and from $8.65 \%$ to $17.28 \%$, respectively.
\end{abstract}

Key words: biodiversity, conservation, $c y t b$, mtDNA, phylogeny, polymorphism, taxonomy

\section{Introduction}

Parosphromenus is a group of small labyrinth fish found in the Malay Peninsula and Sumatra and Borneo Islands (Kottelat \& Ng 1998; 2005). Fishes in this genus are restricted to lowland forest streams and peat swamps, which are heavily vegetated. The first described taxon was $P$. deissneri from Bangka Island (Bleeker 1859). Since then, 20 additional species have been named. Ten species were found on Borneo Island, including P. parvulus (Vierke 1979), P. filamentosus (Vierke 1981), P. allani (Brown 1987), P. anjunganensis (Kottelat 1991), P. linkei (Kottelat 1991), P. ornaticauda (Kottelat 1991), P. pahuensis (Kottelat \& Ng 2005), P. opallios (Kottelat \& Ng 2005), P. quindecim (Kottelat \& Ng 2005), and P. barbarae (Tan \& Grinang 2020). Five species were found on Sumatra and its adjacent islands, including P. deissneri (Bleeker 1859), P. sumatranus (Klausewitz 1955), P. bintan (Kottelat \& Ng 1998), P. gunawani (Schindler \& Linke 2012), and P. phoenicurus (Schindler \& Linke 2012). Six from Malay Peninsula, including P. paludicola (Tweedie 1952), P. nagyi (Schaller 1985), P. harveyi (Brown 1987), P. alfredi (Kottelat \& Ng 2005), P. tweediei (Kottelat \& Ng 2005), and P. rubrimontis (Kottelat \& Ng 2005).

Herein we describe two new species of Parosphromenus from Indonesia. In the present study, we introduced the molecular analysis of the cytochrome $b(c y t b)$ gene into the diagnoses of new species of this genus for the first time. The phylogenetic tree shows that populations from Bangka Island and Kalimantan are monophyletic groups 
distinct from their congeners (Fig. 4). Genetic divergence among these specimens and other taxa in the phylogenetic tree range from $2.44 \%$ to $19.52 \%$ and from $8.65 \%$ to $17.28 \%$, respectively (Supplementary Table S2). The results of molecular analysis are consistent with those of the morphological diagnoses, in which these two groups can also be distinguished by their autapomorphic traits. Based on an analysis of phylogenetic separation, genetic divergence, and morphological differences, we formally describe them as two novel species: Parosphromenus juelinae, sp. nov., and Parosphromenus kishii, sp. nov.

\section{Material and methods}

Field surveys were conducted in Indonesia between 2017 and 2019 and specimens were collected and preserved in 95\% ethanol. Holotypes and some paratypes were deposited at MZB, Museum Zoologicum Bogoriense, Indonesian Institute of Sciences (LIPI), Cibinong, Bogor, Indonesia. Other paratypes and non-type specimens were deposited, with the appropriate permissions, at NCUMB, Museum of Biology, School of Life Science, Nanchang University, China; Shi, Wentian (SJD), Tübingen, Germany and the collection of Kishi, Hiroyuki (CKH), Tokyo, Japan. Considering that the two new species are each restricted to small areas, the exact localities are withheld to avoid potential pressure on the wild population. Qualified researchers can request the information from the first author or MZB.

Measurements were taken with digital calipers to the nearest $0.1 \mathrm{~mm}$. Counts and morphometric data were taken following Kottelat \& Ng (2005). Meristic modal count is indicated by “*”. Considering the difficulties involved in replicating the measurement of dehydrated and damaged specimens, meristic counts and morphometric measurements were obtained only from well-preserved specimens. Kottelat \& Ng (1998) and Tan \& Grinang (2020) suggested that the male color pattern is an important diagnostic characteristic of Parosphromenus. These key meristic counts combined with the coloration of live and preserved specimens are the primary morphological evidence distinguishing the new species from their congeners. The current study follows the phylogenetic species concept (Cracraft 1989; Warren 1992; Turner 1998) that considers a species to be a monophyletic group with autapomorphic traits. This concept has been consistently employed in taxonomic studies of this genus (Kottelat \& Ng 1998, 2005; Schindler \& Linke 2012; Tan \& Grinang 2020).

To build a phylogeny of Parosphromenus and evaluate the genetic distance between the new species and their congeners, the mitochondrial cytochrome $b$ gene was amplified and sequenced following the method of Rüber $e t$ al. (2004). A total of 31 specimens representing nine nominal and the two new species of Parosphromenus and one outgroup taxon (Sphaerichthys osphromenoides) were included (Supplementary Table S1). Maximum-likelihood (ML) and neighbor-jointing (NJ) approaches were used to determine the phylogenetic relationships between the new species and other members in the genus Parosphromenus (Fig. 4). Uncorrected pairwise genetic distances (pdistance) between species were estimated using MEGA X (State College, PA, USA, Kumar et al. 2018) (For further details see Supplementary Methods and Supplementary Table S2).

\section{Taxonomy}

\section{Parosphromenus juelinae, new species}

(Figures 1-4)

urn:lsid:zoobank.org:act:B3BD985C-28D1-4CFE-B440-9D369055B269

Parosphromenus bintan-Kottelat \& Ng, 1998: 270 (ZRC30815).

Parosphromenus deissneri-Tan \& Ng, 2005: 131 (ZRC 46184).

Holotype MZB 25116, male, 19.5 mm SL; Indonesia, Bangka Island, exact locality withheld; colls. Y. H. Ji, 23. Mar. 2017.

Paratypes MZB 25117, female, 16.2 mm SL; NCUMB 65121, 13 specimens, 12.3-19.5 mm SL; same data as for holotype; SJD BA2021-2023, 28 ex. 13.6-32.3 mm SL; same data as for holotype, colls. Y. H. Ji \& H. Kishi, 26 Mar. 2017; W.T. Shi \& J. L. Wang, 30 Sep. 2019;

Diagnosis Parosphromenus juelinae, sp. nov., is distinguished from other species of the genus by the following unique combination of characters: the inner iridescent band in the unpaired fins is fragmented into an arc arrange- 
ment of several clearly interrupted irregular blotches (when preserved, these iridescent blotches become hyaline); the proximal part of the unpaired fins is black; dorsal-fin rays XIII-XIV, 5-7 (total 18-21, 19*); anal-fin rays X-XII, 9-10 (total 19-22, 21*), caudal fin rounded with a branched media ray, pelvic fin filament light blue; except for the dark brown stripes, the rest of the body is covered throughout by intense red blotches, which extend to the base of the unpaired fins.

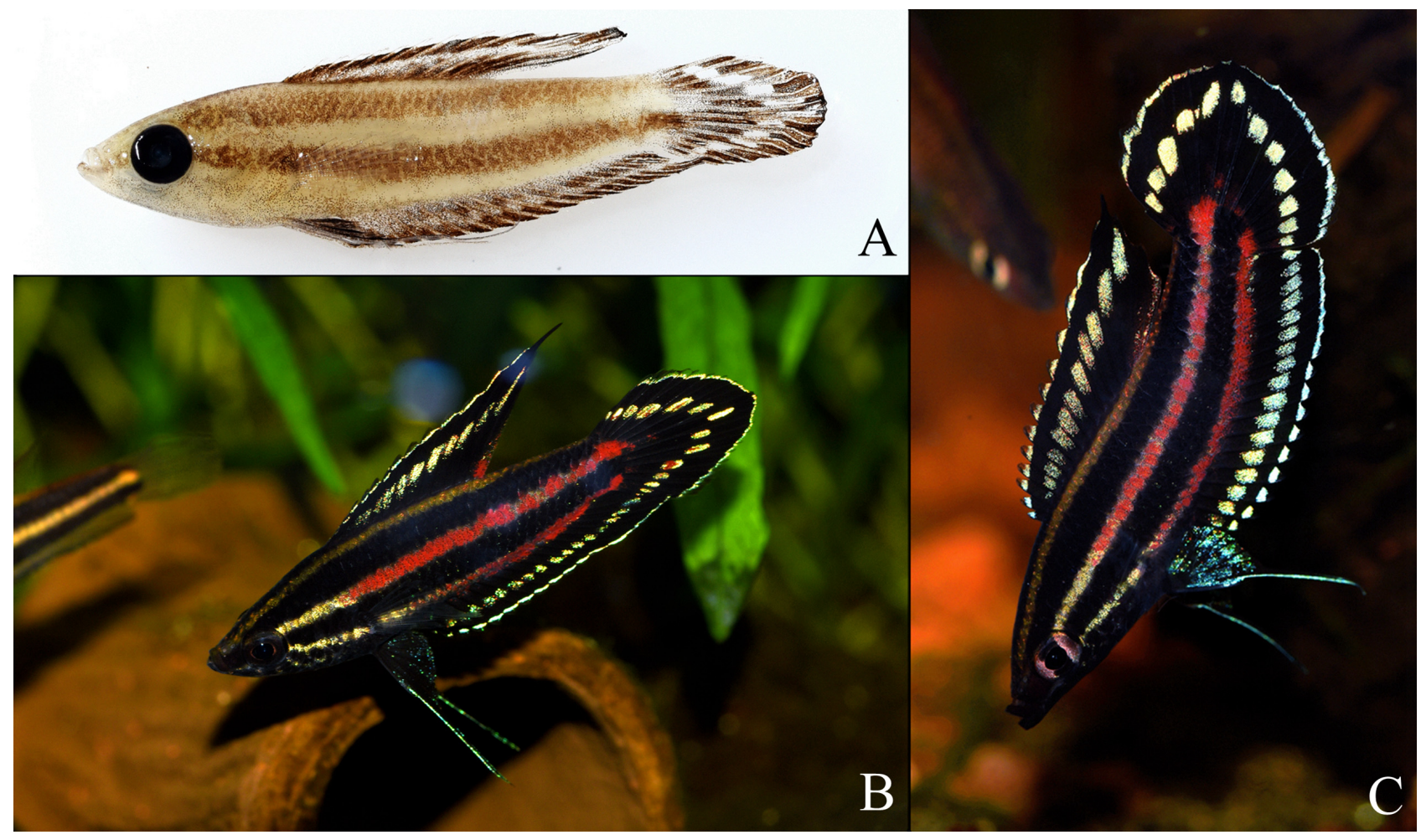

FIGURE 1. (A) Parosphromenus juelinae sp. nov., MZB 25116, 19.5 mm SL male holotype; (B) P. juelinae, about $31 \mathrm{~mm}$ SL, male, from type locality, live coloration, not preserved (laterally inverted); (C) P. juelinae, male in "head-down" courtship position, not preserved (laterally inverted).

Description Morphometric and meristic data are summarized in Table 1. General body shape and coloration are presented in Fig. 1 A-C. Head pointed, long $(25.3 \%-37.9 \%$ SL); body slightly stocky $(22.7 \%-33.7 \%$ SL, mean $28.1 \%$ at dorsal-fin origin). Dorsal-fin origin usually above $4^{\text {th } *}-5^{\text {th }}$ scale of lateral scale series. Dorsal-fin with XII 6 (3), XII 7* (8), XIII 7 (2), XIV 7 (1) rays, total 18 (3), $19 *$ (8), 20 (2) or 21 (1). Dorsal-fin posterior portion pointed distally, reaching beyond caudal-fin base in male, rounded and shorter in female. Caudal fin rounded, with 3 simple, $5+6$ branched and 2 simple rays. Anal-fin origin below $4^{\text {th }}$ spine of dorsal fin, posterior portion slightly pointed in male, rounded in female, with X, 9 (1) X, 10 (2), XI, 9 (2) or XI, 10* (9), XII, 10 (1) total 19 (1), 20 (4), $21 *(9) 22$ (1) rays. Pectoral fin rounded, with $12(2), 13(5)$ or $14 *(8)$ rays. Pelvic fin with one spine, 1 simple and 4 branched rays, with a long filament reaching about $12^{\text {th }}-13^{\text {th }}$ anal-fin ray; lateral scales 29 (6), or $30^{*}(9)$, plus 2 to 3 scales on caudal-fin base; $9(8)$ or $10^{*}(7)$ scales in transverse series upward from $4^{\text {th }}$ anal-fin spine; $11(8)$ or $12^{*}$ (7) transverse scales at dorsal fin origin.

Live coloration Male (Fig. 1 B, C): Head with a yellowish to light brownish background. Dark brown stripes running through flank from snout to caudal peduncle. Sub-orbital and opercular area fully covered by black blotches (less distinct in stressed or preserved specimens). Except for dark brown stripes, body is almost entirely covered by intense red blotches (less intense at anterior part between dorsal-fin base and first dark brown stripe and belly regions). These red blotches turn into a rose-pink tint when fish is stressed; unpaired fins with a bright bluish margin and a narrow black subdistal band; between subdistal band and proximal part, a row of bright turquoise/greenish blotches present, distinctly interrupted by rays of fins (Fig. 2 A-C). Proximal parts of unpaired fin mainly black, but red blotches on flank extend to posterior part of dorsal-, anal-fin base and around caudal-fin base. Pelvic fin iridescent bluish, with a bright bluish filament. Pectoral fin hyaline.

Female: Head and body coloration similar to male, but red blotches less intense. Dorsal, anal and caudal fin 
hyaline without iridescent band. In breeding condition, faint reddish color can be observed in proximal parts of unpaired fins. Pelvic fin filament bluish. Pectoral fin hyaline.

Preserved coloration Male (Fig. 1. A): head and body with a whitish or light yellowish ground color (red blotches on body flank in live are not apparent when preserved); a dark brown stripe running from snout through eye and along whole dorsum to caudal-fin base; a second parallel stripe present from postorbital area through flank to middle of caudal peduncle; some black pigments can be observed on suborbital, opercular, and a third short stripe present along belly region to middle part of ana-fin base (up to $8^{\text {th }}$ spine of anal fin in holotype). Dorsal, anal and caudal fins with hyaline margin; remaining areas of unpaired fins uniformly brownish with a row of hyaline blotches in the middle. Pectoral fin hyaline. Pelvic fin dark brownish with a hyaline edge.

Female: Head and body coloration similar to male but less intense. Unpaired fins light brownish without distinct patterns, hyaline margin present. Pectoral fin hyaline. Pelvic fin base slightly brownish, filament hyaline.
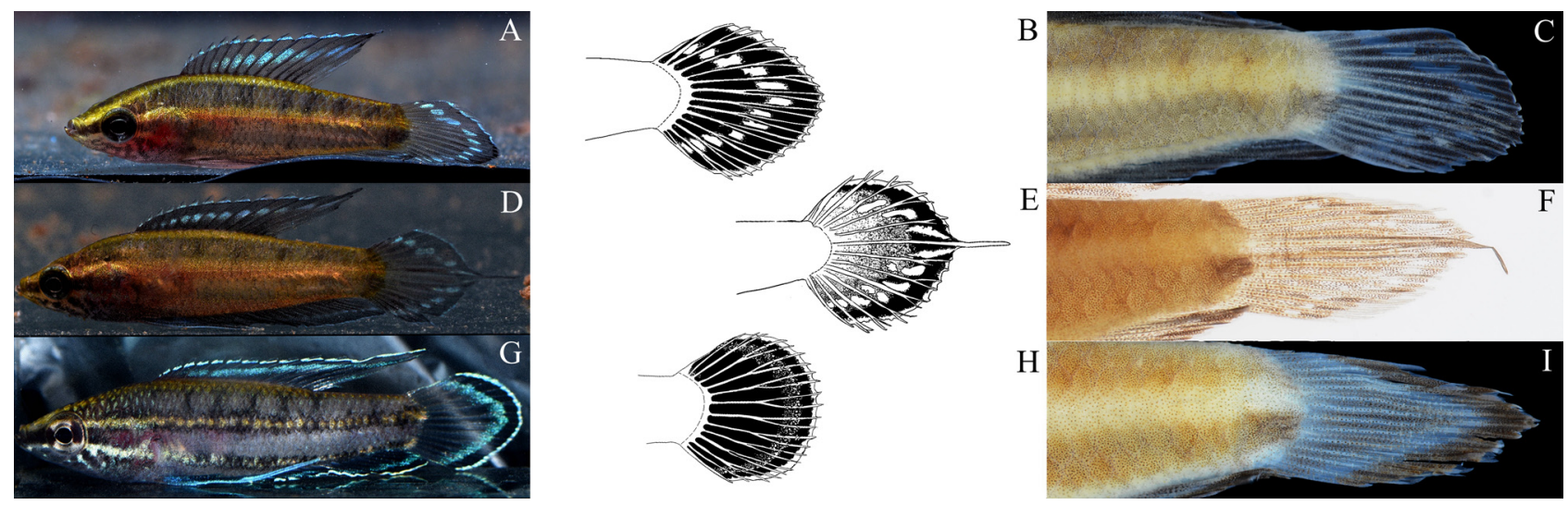

FIGURE 2. (A) P. juelinae, male, same collection data as for holotype, live coloration immediately after collection, not preserved; (B) Schematic diagram of the caudal fin of $P$. juelinae: rounded, median ray branched, a row of interrupted bluish blotches, proximal part black (illustrator: Feng Xu); (C) Details of the caudal fin of P. juelinae, ZRC 46184 (photograph: Tan H. H., 26. Jan. 2021); (D) Parosphromenus deissneri, male, near location of neotype, live coloration after capture, coll. Y. H. Ji \& H. Kishi, Mar. 2017, not preserved (laterally inverted); (E) Schematic diagram of the caudal fin of P. deissneri: lanceolate, median ray filamentous and simple, a row of interrupted bluish blotches, proximal part brownish (illustrator: Feng Xu); (F) Details of the caudal fin of P. deissneri, ZRC 31017 (photograph: Tan H. H., 19. Apr. 2021); (G) Parosphromenus bintan, male, south of location of paratype ZRC 31327-31331, Bangka Island, live coloration after capture, coll. Y. H. Ji \& H. Kishi, Mar. 2017, not preserved; (H) Schematic diagram of the caudal fin of P. bintan: rounded, median ray branched, a continuous bluish band, proximal part black (illustrator: Feng Xu); (I) Details of the caudal fin of P. bintan, ZRC 41403 (photograph: Tan H. H., Jan. 2021).

Comparison Parosphromenus juelinae sp. nov. differs from its most similar congener, P. deissneri, in the following combination of characteristics: caudal fin rounded in $P$. juelinae (vs. lanceolate with a filamentous median ray in P. deissneri), median ray branched (vs. simple filamentous) (Fig. 2 D-F; S1), base color of the proximal part of the unpaired fins black (vs. dark reddish to brownish), presence of a bluish margin in the posterior part of the median ray of the caudal fin (vs. absence), fewer anal-fin spines (X-XII, XI*, vs. XII-XIII*), a slightly greater body depth at dorsal-fin origin (22.7-33.7\% SL, mean $28.1 \%$ SL vs. 26.2-27.2, mean 26.8), a shorter dorsal-fin base (29.5-46.1\% SL, mean 37.7\%SL vs. 38.4-46.0, mean 42.0), a greater interorbital width (25.8-34.9 \% HL, mean $30.4 \% \mathrm{HL}$ vs. $21.0-26.0$, mean 23.5 ). It is also distinguished from other similar species: P. bintan, P. gunawani and P. nagyi, by the presence of intense red blotches on the flank (vs. absence) and a row of interrupted iridescent bluish blotches on the caudal fin (vs. a continuous iridescent band) (Fig. 2 G-I; S2); further, it is distinguished from $P$. bintan by a distinct dark brown stripe along the belly region to anal-fin base (vs. absence or not distinct), when preserved. It also differs from $P$. harveyi and $P$. nagyi by having a median row of hyaline blotches in the dorsal and anal fins (vs. absence), when preserved; further it is distinguished from $P$. harveyi by the light blue pelvic fin filament (vs. entirely or partly black) and from $P$. nagyi by the lack of a black blotch or spot in the pelvic fin base (vs. presence). It differs from $P$. allani and $P$. barbarae, which also possess intense red blotches on the flank, in the black background color of the dorsal and caudal fins with a row of entirely bluish blotches (vs. reddish fins without such a bluish pattern), and lacking a dorsal or caudal fin ocellus (vs. presence). Parosphromenus juelinae can be further 
distinguished from $P$. paludicola by having fewer spines on the dorsal fin (XII*-XIV, vs. XVII*-XIX); from $P$. linkei and $P$. pahuensis by the lack of black blotches in the middle of the lateral stripes (vs. presence) and the black base color of the unpaired fins (vs. orange/reddish); from P. ornaticauda and P. parvulus by having more spines in the anal fin (X-XII, XI*, vs. VII-IX) and more spines in the dorsal fin (XII*-XIV, vs. IX-XI); from P. filamentosus by a rounded caudal fin (vs. lanceolate, with a non-branched median filamentous ray) and a black proximal part of the unpaired fins (vs. reddish); from P. sumatranus by the lack of an ocellus on the dorsal fin (vs. present) and a black caudal fin with a row of bluish blotches (vs. uniformly reddish); from $P$. anjunganensis by a narrow dark subdistal band margined interiorly by a row of bluish blotches in unpaired fins (vs. uniformly reddish); from $P$. quindecim, by fewer anal-fin spines (X-XI*, vs. XIII), and lack of bluish spots in the proximal part of caudal fin (vs. presence); and from P. alfredi, P. opallios, P. phoenicurus, P. rubrimontis, and P. tweediei by a row of interrupted bluish blotches on the unpaired fins (vs. a partly or completely reddish band).

Distribution Parosphromenus juelinae sp. nov. is restricted to a small area on Bangka Island, Indonesia, where it occurs in a few forest peat swamps with little human interference.

Etymology This species is named after Juelin Wang, who collected the specimens along with Wentian Shi, and whose inspiration and assistance made this study a success.

Field notes This species is restricted to a few adjoining forest streams and swamps belonging to the same river system in Bangka, which are not connected with the habitats of $P$. bintan and $P$ deissneri. The habitats are wellpreserved and relatively undisturbed by human activities. The water bodies are densely vegetated with aquatic macrophytes (mainly Cryptocoryne bankanensis [Araceae] and Utricularia sp. [Lentibulariaceae]) and shaded by trees and shrubs at the bank; and the water is clear, with high tannin levels, giving a black-tea color (Fig. 3). As these are less disturbed habitats, the population density was once very high. In 2017, over 100 specimens were collected from a water pool (about $\left.20 \mathrm{~m}^{2}\right)$ within 40 minutes using three hand nets $(60 \mathrm{~cm} \times 40 \mathrm{~cm}$ with $4 \mathrm{~mm}$ mesh size) in the rainy season. However, the edge of the distribution area of this species is now under growing pressure from agricultural activities. The swamp of the above-mentioned collection location in 2017 has been drained and converted into a paddy field in 2019; thus, likely extirpating the population.

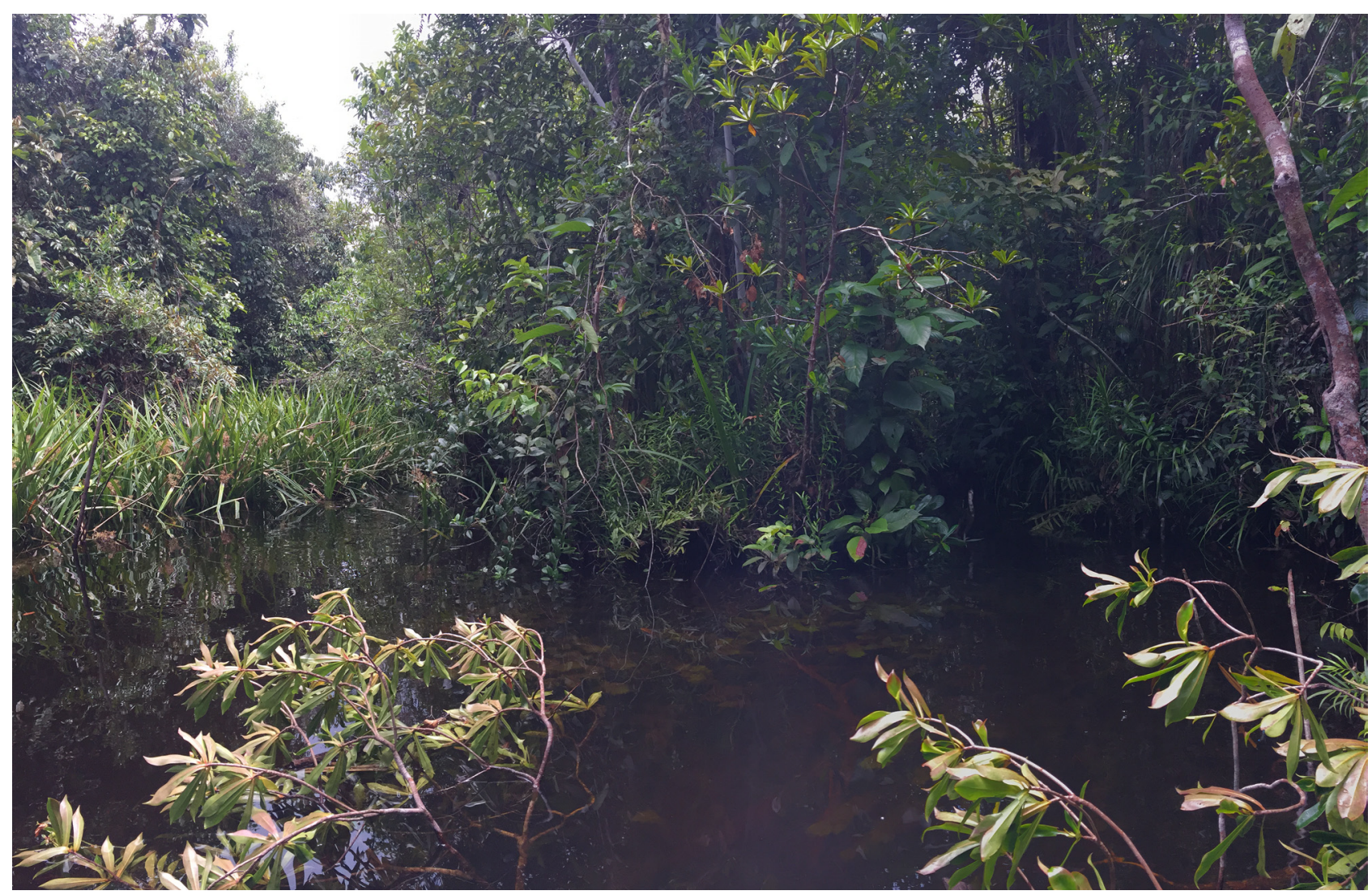

FIGURE 3. Photograph of type locality of Parosphromenus juelinae in Bangka Island, a black water forest peat swamp, Sep. 2019. 
All the syntopic fish species recorded from the habitats include: Channa bankanensis (Channidae), Eirmotus cf. octozona (Cyprinidae), Paedocypris sp., Rasbora einthovenii, Rasbora kalochroma, Sundadanio gargula, Trigonopoma gracile and Trigonopoma pauciperforatum (Danionididae), Nandus nebulosus (Nandidae), Belontia hasseltii, Betta chloropharynx, Betta edithae, Betta schalleri, Betta simorum, Luciocephalus pulcher, Sphaerichthys osphromenoides (Osphronemidae), Hemirhamphodon pogonognathus (Zenarchopteridae). No other Parosphromenus species were recorded.

Conservation status On Bangka Island, natural lowland habitats are seriously affected by mining activities, oil-palm plantations, and human settlement. During the field surveys on this island from 2016 to 2019, we observed dramatic habitat loss and degradation of natural landscapes, and in 2018 we noticed that the edge of the type locality had been disturbed by agricultural activities. Following the IUCN Red List Categories and Criteria (ver. 3.1), we propose Parosphromenus juelinae sp. nov. be listed as Critically Endangered B2ab (iii), based on its very restricted distribution area in a single river system on a single small island $\left(<50 \mathrm{~km}^{2}\right)$ with less than three known locations; and the fact that this habitat has been facing direct threats from human activities since 2018. Since there are no significant environmental conservation projects in this area, the survival of this species in the near term is clearly imperilled.

Molecular analysis The consensus phylogenetic tree based on the mitochondrial cytb gene suggests that Parosphromenus juelinae sp. nov. is a monophyletic group distinct from its sister group $P$. deissneri by an uncorrected p-distance of 2.44\% (Fig. 4; Table S2). Parosphromenus. juelinae is significantly distinct from other species, for which $c y t b$ data are available with a p-distance ranging from $6.88 \%$ to $18.95 \%$. These results indicate that the genetic differences between the new species and its congeners exceed the intraspecific differences observed $(<1 \%$ in the current study, no published comparable data are known from earlier studies) (K2P $<0.5 \%$ in related labyrinth fish species like Channa argus, Zhou et al. 2018). Morphologically, P. juelinae differs from all known Parosphromenus species (see above Diagnosis and Comparison). Thus, based on both a statistically significant morphological diagnosis based on 43 examples and a cytb divergence consistent with that between other sister-pairs of anabantoids fishes, we are confident that, these specimens from Bangka do in fact represent a valid species.

Remarks Kottelat and Ng (1998) noticed that the specific combination of caudal-fin shape and color pattern to be consistent within a population of Parosphromenus on Bangka Island. Based on this observation, they distinguished P. bintan: the populations with shape1 (caudal fin rounded with branched median ray) and pattern1 (continuous bluish band) from $P$. deissneri: shape2 (lanceolate with simple filamentous ray) and pattern2 (a row of interrupted bluish oval blotches). There was a controversial single claim by N. Neugebauer and K. Frank in 1994 that $P$. bintan and $P$. deissneri are syntopic, viz. different combinations of characteristics could be found in a single population in a location $8 \mathrm{~km}$ from Air Bara towards Pajung, which has been cited by Kottelat \& $\mathrm{Ng}(1998)$ with a note of caution that the specimens mentioned were not examined. This claim was also mentioned by Linke (2014). However, this single report of syntopy in Bangka has not been substantiated by other authors. In 2000, D. Armitage and A. Brown visited this location and recorded only a single species of Parosphromenus (Armitage 2002). Further, the Air Bara-Kota Koba area was surveyed regularly by Kishi from 2000 to 2017, but no syntopic of Parosphromenus were found (pers. comm.). In the 2008 survey by H. Linke too, no syntopy was reported around Air Bara (Linke 2014, pers. comm.). At least since 2017 this river has been severely polluted by Tin mining. We are thus no longer able to substantiate this report. Recently, a local fish conservation organization (Travonim 2021, per. comm.) too, confirmed that only a single species of Parosphromenus could be recorded in the Air Gegas area (Air Bara is a village of this area). Meanwhile, during our own surveys between 2016-2019, we did not find any species of Parosphromenus in syntopy in this region or anywhere else in the island. Our field surveys suggest that each of the species is distributed exclusively in different drainages: P. deissneri in the Sungai Baturusa basin (river system of the original type locality) and Sungai Kurau basin (locality of neotype) towards east coast; P. bintan in the Sungai Kotawaringin basin (our survey 2016) and Sungai Menduk basin (our survey 2017) towards west coast and $P$. juelinae in rivers draining towards the north coast (location data can be requested from MZB and first author). These results are consistent with Kottelat and Ng's (1998) observation that characteristics are constant within the population from each specific location.

Thus, there is no reason to discard the principle that the unique combination of shape and pattern of the caudal fin constitutes a diagnostic criterion of a species in this genus. The populations of $P$. juelinae discovered in distinct drainages can be morphologically distinguished from the other two known species following this criterion based on 
a different but consistent combination of characteristics: shape1 \& pattern2 (Fig. 2). The validity of this morphological difference is further supported by the molecular analysis, which shows that these three species represent three distinct monophyletic groups with characteristic morphological traits.

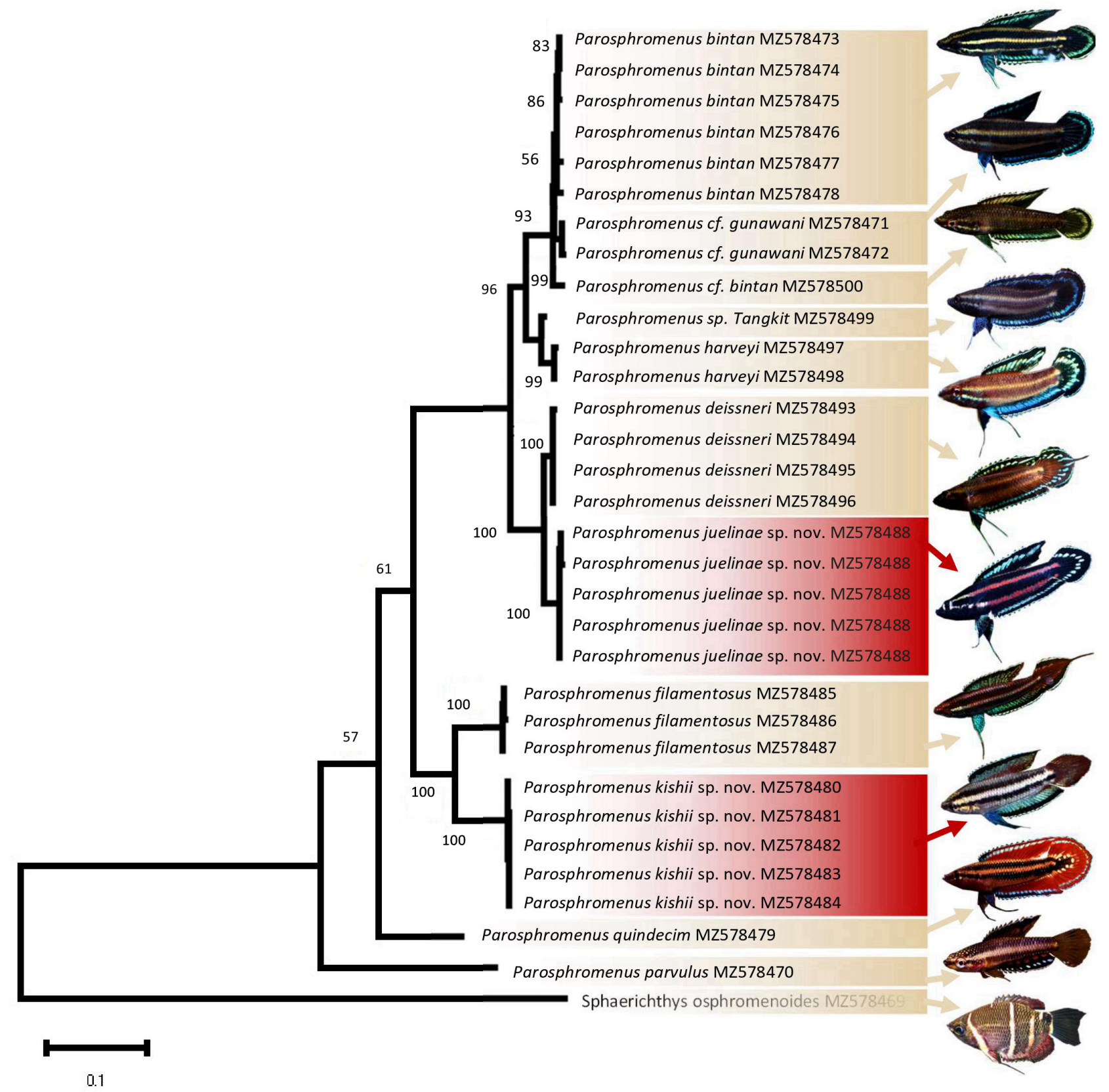

FIGURE 4. Phylogenetic tree of Parosphromenus species based on cytb gene sequences and ML approaches. The two new species in the phylogenetic tree are highlighted in red (Photograph of Parsophromenus parvulus: Jianhui Dai, 2019; Photograph of Parsophromenus harveyi; Parosphromenus sp. Tangkit: Ji, Yuhan Ji, 2017; Photograph of Parsophromenus cf. gunawani: Weilin Zhong, 20. Apr, 2020).

There are two series of specimens deposited in Lee Kong Chian Natural History Museum, ZRC30815 from Bangka-Belitung and ZRC46184 from 'Biliton', Sumatra (Fig. S3-S4) labeled as P. bintan (Kottelat \& Ng 1998) and $P$. deissneri (Tan \& Ng 2005), respectively. These are distinct from P. bintan and P. deissneri, but morphologically similar to P. juelinae. A clarification of their taxonomic status is beyond the scope of the current description (See Supplementary Notes of Comparative Materials and Supplementary Figures for more details). 


\section{Parosphromenus kishii, new species}

(Figures 4-7)

urn:lsid:zoobank.org:act:03A7E23D-B1DE-4A33-9F25-38ED817B707B
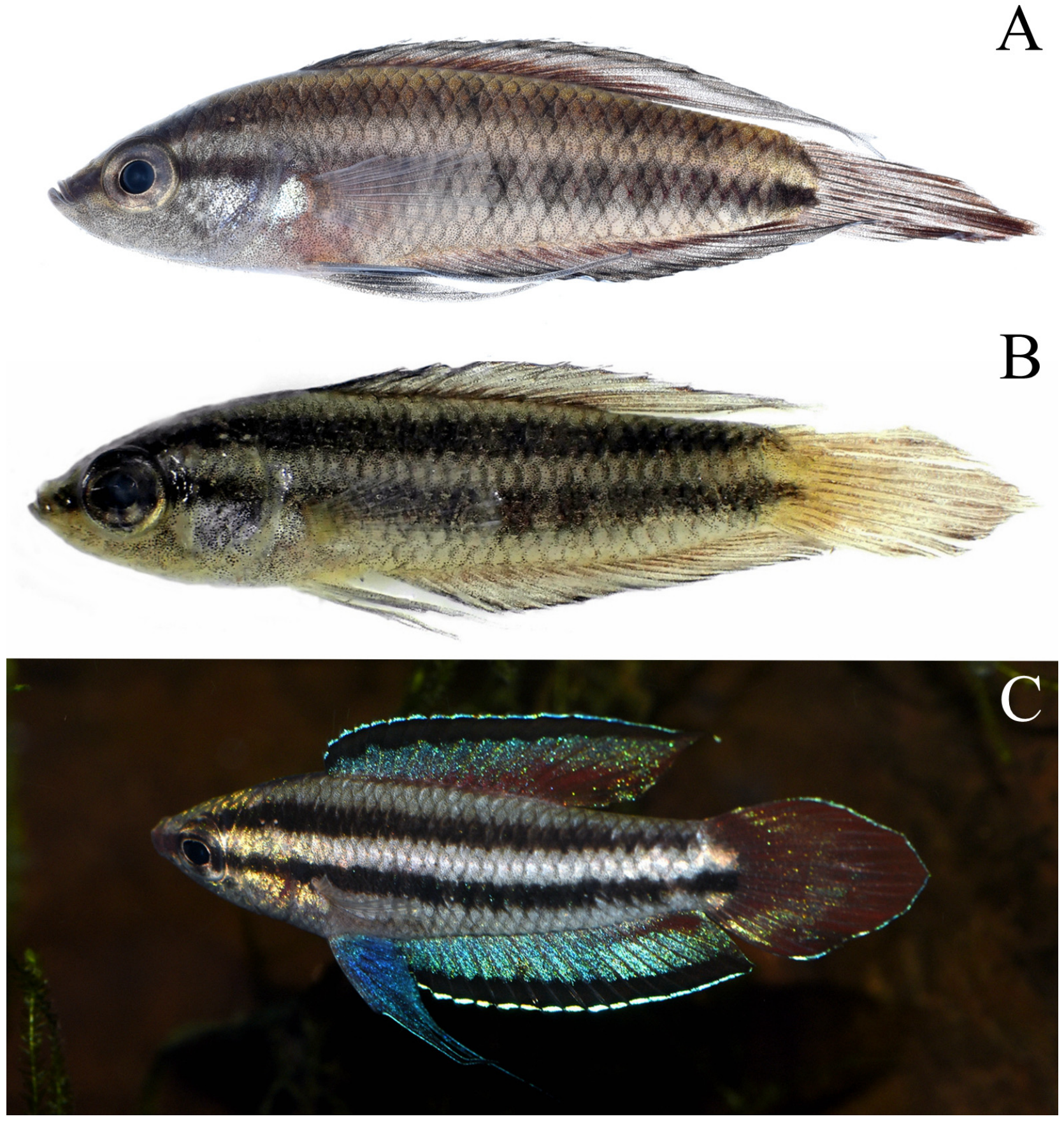

FIGURE 5. (A) Parosphromenus kishii sp. nov., MZB 25120, 31.4 mm SL male holotype, freshly preserved (laterally inverted); (B) P. kishii, CKH-P102, 27.5 mm SL, male paratype (photograph: H. Kishi, Jan. 2021); (C) P. kishii, about 35 mm SL, male, from the type locality, live coloration, not preserved.

Holotype MZB 25120, male, 31.4 mm SL; Indonesia, Borneo Island, Kalimantan Tengah, exact locality withheld; colls. H. Kishi, 13. Apr. 2019.

Paratypes MZB 25121, female, 1 specimen, 16.2 mm SL; NCUMB 65135, 8 specimens, 12.3 -15.4 mm SL; SJD KA2081, 7 specimens. 15.6-32.1 mm SL; same data as for holotype. colls. H. Kishi \& W. T. Shi, 13. Apr. 2019.

Diagnosis Parosphromenus kishii, sp. nov., is distinguished from its congeners by the following unique combination of characteristics: the unique caudal fin coloration, consisting of a uniformly reddish background; irregular 
faint turquoise blotches of differing sizes scattered on the central region of the caudal fin, vaguely forming a band without clear outline; caudal fin pointed rhombic shape; a long dorsal fin with XIII-XIV spines and 7-8 segmented rays (total 20-22, mode 20); anal-fin rays XII-XIII, 9-10 (total 22-23, mode 22); a broad light bluish iridescent band in dorsal- and anal-fin; pelvic fin and filament uniformly bluish.

Description Morphometric and meristic data are summarized in Table 1. General body shape and coloration are shown in Fig. 5 A-C; head stocky and long (27.3-39.4 \% SL); body slightly stocky (16.0-43.4 \% SL, mean 31.9 $\% \mathrm{SL}$ at dorsal-fin origin). Dorsal-fin origin usually above $4^{\text {th } *}-5^{\text {th }}$ scale of lateral scale series. Dorsal-fin rays: XIII 7 (4), XIII 8 (1), XIV 6 * (3) or XIV 8 (1) rays, total 20 (7)* 21 (1) or 22 (1). Dorsal-fin posterior portion pointed, reaching slightly beyond caudal-fin base in male, slightly pointed but shorter in female. Caudal fin shape variable, but mainly pointed-rhombic in adults (see Remarks for details of polymorphism in caudal shape) (Fig. 7); caudal fin with 3 simple, $5+6$ branched and 2 simple rays. Anal-fin origin below $3^{\text {rd }}$ spine of dorsal-fin, posterior portion slightly pointed in male, round in female: XII, 10 (3), XIII, 9 (4)* or XIII, 10 (2), total 22 (7) * or 23 (2). Pectoral fin rounded, with 12 (2), 13 (4)* or 14 (3) rays. Pelvic fin with one spine, 1 simple and 4 branched rays, with a long filament reaching about $11^{\text {th }}$ anal-fin ray; lateral scales 29 (4), or $30^{*}(5)$, and 2-3 scales on caudal-fin base; $9^{*}$ scales in transverse series upward from $4^{\text {th }}$ anal-fin spine; $11 *$ transverse scales at dorsal fin origin.

Live coloration Male (Fig. 5. C): Head with yellowish to grayish background. Body with grayish background color. Dark brown stripes running through flank from snout to caudal peduncle. Opercular area covered by golden sheen. Dark brown blotches on suborbital area less distinct. Dorsal and anal fins with bright bluish margin and narrow black subdistal band, followed interiorly by a broad turquoise band; interior boundary of band is less regular; anterior region of proximal part often covered by turquoise band, posterior region reddish. Caudal fin with a bright bluish margin; background uniformly reddish, irregular faint turquoise blotches scattered at center of caudal fin forming a vague crescentic pattern without clear outline. Pelvic fin iridescent turquoise bluish, with a dark bluish filament. Pectoral fin hyaline.

Female: head and body coloration similar to male. Coloration of dorsal and anal fin similar to male but less intense; caudal fin hyaline without unique pattern. Pelvic fin filament slightly bluish. Pectoral fin hyaline.

Preserved coloration Male (Fig. 5. A, B): head and body with whitish or light yellowish ground color; a dark brown stripe running from snout through eye along whole dorsum to caudal-fin base; a second parallel stripe present from postorbital area through flank to middle of caudal peduncle; less distinct black pigments observed on suborbital and opercular area; belly whitish without a third dark stripe. Dorsal and anal fins with hyaline margin, a narrow dark subdistal band bordered interiorly by broad hyaline band, proximal part from dark reddish to brownish. Caudal fin with a hyaline margin, remaining parts uniformly dark reddish to brownish with irregular faint hyaline blotches in middle. Pectoral fin hyaline. Pelvic fin base dark brownish with a hyaline filament.

Female: general coloration similar to male but less intense. Caudal fin light brownish without any pattern.

Distribution The species is currently only found in a small river running through a large oil-palm plantation in Kalimantan Tengah, Indonesia.

Etymology The species is named after Hiroyuki Kishi, who discovered this species and P. quindecim and who contributed much first-hand field information on this genus over the last decade.

Comparison Parosphromenus kishii sp. nov. can be easily distinguished from all other Parosphromenus by its unique reddish caudal fin with an irregular faint turquoise pattern and pointed rhombic shape; it also differs from $P$. deissneri and $P$. filamentosus by a non-filamentous branched median ray of the caudal fin (vs. simple and filamentous) and having more dorsal-fin spines (XIII-XIV* vs. XII-XIII); from P. ornaticauda and P. parvulus by more anal-fin spines (XII-XIII* vs. VII-IX) and more dorsal-fin spines (XIII-XIV* vs. IX-XI); from $P$. linkei and $P$. pahuensis by the lack of black blotches in the middle of the flank stripes (vs. presence) and presence of a subdistal band in the dorsal and anal fins (vs. absence); from P. juelinae by the reddish color of the proximal parts of the dorsal and anal fins (vs. blackish) and by the lack of reddish blotches on the body flanks (vs. presence); from P. opallios by a broad entirely turquoise band throughout the dorsal and anal fin (vs. a narrow partly or entirely reddish band); from $P$. quindecim by a broad turquoise band on blackish dorsal and anal fins (vs. narrow) and the light bluish pelvic fin filament (vs. black); P. kishii is distinguished from P. allani, P. barbarae and P. sumatranus by the lack of an ocellus on the dorsal fin (vs. presence); from $P$. anjunganensis by the turquoise band and blotches on the unpaired fins (vs. uniformly reddish); from $P$. bintan, $P$. harveyi, $P$. nagyi and $P$. gunawani by a reddish proximal part of the dorsal and anal fins (vs. black); from P. alfredi, P. phoenicurus, P. rubrimontis, and P. tweediei by a broad entirely turquoise band throughout the dorsal and anal fins (vs. a narrow partly or entirely reddish band). 
Field notes The species was recorded by H. Kishi in Kalimantan Tengah as early as Nov. 1999. Currently it is only found in a single river, which is severely disturbed by human activities (Fig. 6). Most of the nearby regions have been converted into oil-palm plantations. Thus, we have yet not been able to record this species outside this single river. There are still some remote locations with better potential, which have not been explored in the last survey. Further studies will be necessary to clarify the distribution of this endangered species.

All the syntopic fish species recorded from the habitats are listed as follows: Trigonopoma pauciperforatum (Danionididae), Nandus nebulosus (Nandidae), Betta edithae, Luciocephalus aura, Sphaerichthys selatanensis (Osphronemidae) and Hemirhamphodon tengah (Zenarchopteridae).

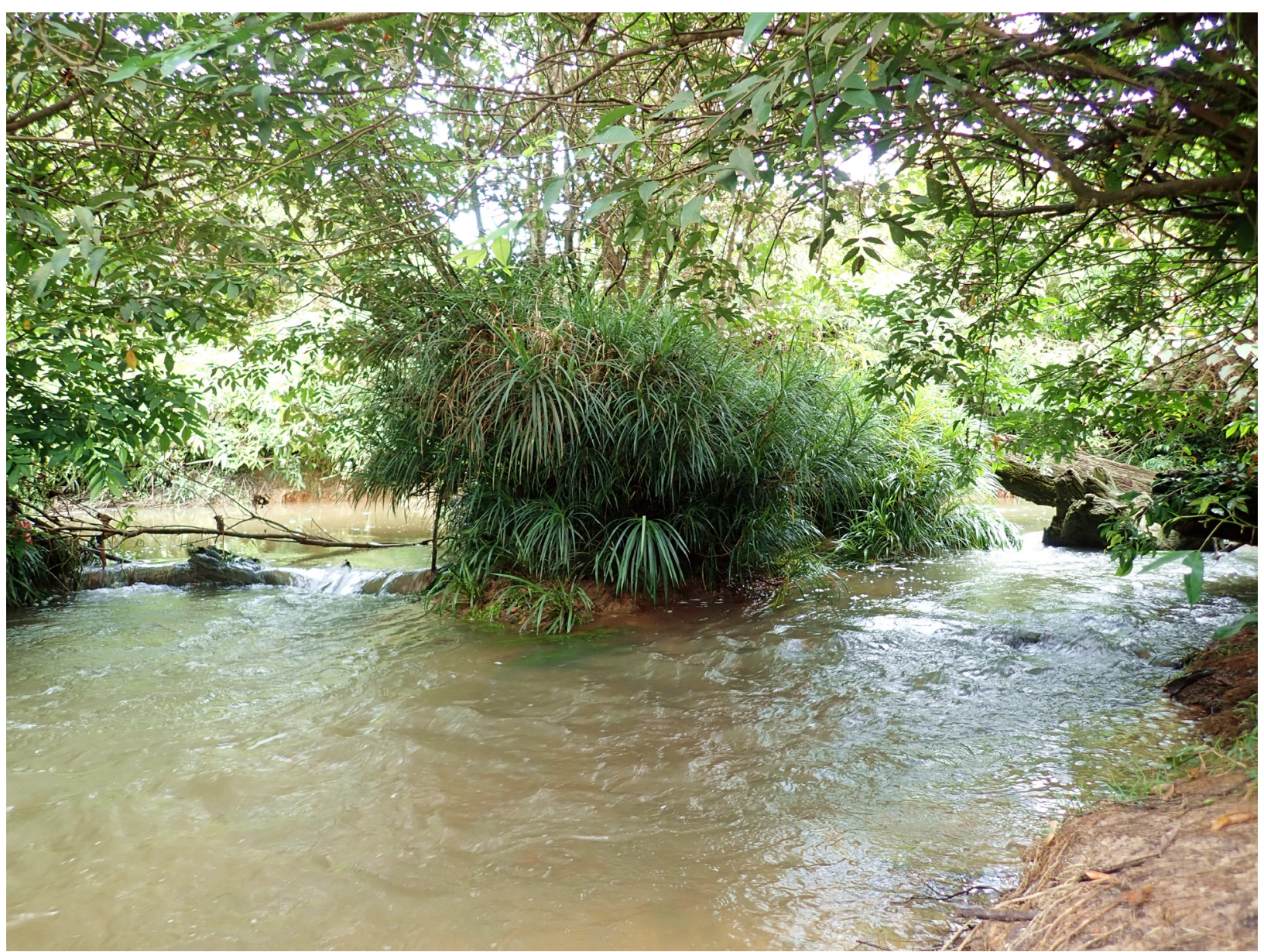

FIGURE 6. Photograph of type locality of Parosphromenus kishii in Kalimantan Tengah, a clear water river running through an oil-palm plantation, Apr. 2019.

Conservation Status Parosphromenus kishii sp. nov. is confined to a single river, which now functions as a natural irrigation canal for a large oil-palm plantation. The habitat is extremely impacted. Any further works at the plantation may lead to dredging and expansion of this river, which may eradicate the only known population of this species. Thus, following the IUCN Red List Categories and Criteria (ver. 3.1), we propose that this species be listed as Critically Endangered B2ab (iii, v), based on its very restricted distribution within a single river running through an oil-palm plantation $\left(<50 \mathrm{~km}^{2}\right)$ with only a single known location and the extremely high likelihood of becoming extinct due to the potential works of surrounding oil-palm plantations. Immediate in-situ or ex-situ conservation is highly recommended for this species.

Molecular analysis. The consensus phylogenetic tree based on the mitochondrial cytb gene suggests that Parosphromenus kishii sp. nov. is a monophyletic group distinct from its sister group P. filamentosus by an uncorrected p-distance of $8.65 \%$ (Fig. 4; Table S2). Furthermore, $P$. kishii sp. nov. is substantially distinct from other congeners too, with $c y t b$ genetic distances ranging from $13.84-17.28 \%$. These results suggest that genetic differences among the new species and its congeners is indicative of divergence at a species-level. Morphologically, P. kishii sp. nov. also differs from all known Parosphromenus species in its unique caudal fin coloration. Thus, based on both molecular and morphological data, this fish from Kalimantan Tengah is formally recognized as a distinct species. 


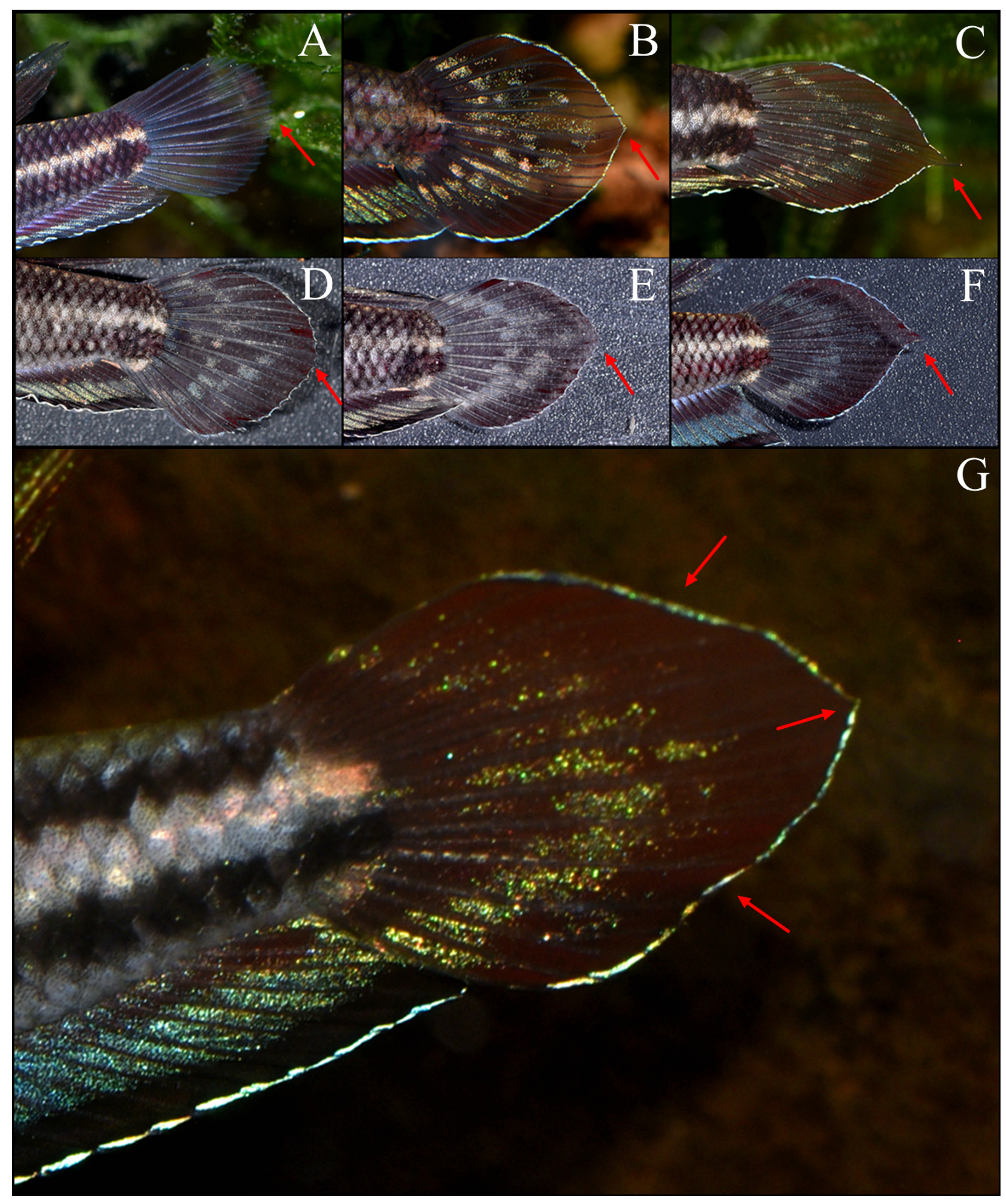

FIGURE 7. (A) The rounded caudal fin of juveniles: posterior edge of the fin smoothy rounded, not pointed; not preserved; (B). The most common rhombic caudal-fin shape in adults, posterior edge of the fin projected outwards into a pointed rhombic shape, SJD KA2081, from type locality; (C). The third variant of the caudal-fin shape, the median ray branched and elongated into a short filament in some adults, SJD KA2081, from type locality; (D) The rounded caudal-fin shape in F1 adults (offspring of the male in Fig. 5 C); (E) The pointed rhombic caudal-fin shape in F1 adults (offspring of the same clutch of the male in Fig. 5 C); (F) The spade-shaded caudal-fin shape with a short filament (median ray branched) in F1 adults (offspring of the same clutch of the male in Fig. 5 C); (G) Another variant of the caudal-fin shape in adults, the middle part of the posterior edge of the caudal fin aberrantly elongated outwardly into a center convex rhombic shape, but without filament; same fish with Fig. $5 \mathrm{C}$, not preserved. (laterally inverted). 
Remarks Different forms of the caudal fin shape can be found within Parosphromenus kishii: a pointed rhombic shape in most specimens (44 out of the 50 collected adult specimens), rhombic with a convex in the middle in specific specimens ( 2 out of 50 ) and lanceolate with a projected short filamentous tip in certain older adults (the median ray branched instead of simple, 4 out of 50) (Fig. 7 A-C, G). Except the convex morph (Fig. 7 G), which might be an aberrant one, other phenotypes have been preserved in the next generation. We observed again in the same batch of F1 from a single pair, three different morphs of caudal fin shapes: round, pointed rhombic and lanceolate with a projected short filamentous tip (Fig. 7 D-F). The rays of the fin are not damaged in the examined specimens, and these shapes are not aberrant due to regrowth following injury. Thus, these distinct caudal fin shapes are most likely a potential polymorphism in this species.

\section{Comparative material examined}

(Also see Supplementary Materials. Fig. S1-4)

Parosphromenus bintan, Paratype: ZRC41403, 1 male, 24.0 mm, same data as Holotype, Indonesia, Riau: Bintan Island: just before $45 \mathrm{~km}$ on road from Tanjung Uban to Tanjung Pinang; Tan H. H. et al., 28 Jun. 1995, photographed in Jan. 2021 (Fig. S2-A, B); ZRC31162, 1 female, 16.5 mm, Indonesia, Bangka-Belitung: Bangka: 4km north of Bikan; M. Kottelat, 3 March 1993; ZRC31327, 1 female, 25.5mm, Indonesia, Bangka-Belitung: Bangka: Kampong Tebing, $65.5 \mathrm{~km}$ east of Mentok on road to Pangkalpinang, small black-water pool in degraded forest, Bangka; M. Kottelat, 4 March 1993;--Topotype: SJD BI 2011, 1 male, same data as Holotype, Indonesia, Riau: Bintan Island; O. J. Bangun, March 2021 (Fig. S2-C);

Parosphromenus deissneri, ZRC31017, 5ex, 18.2-23.2 mm, Indonesia, Bangka-Belitung: Bangka: about $25 \mathrm{~km}$ north of Koba, stream between Desa Kurau and Desa Balilik; M. Kottelat et al., 3 March 1993 (Fig. S1);

Parosphromenus filamentosus, SJD KA 2091, 2ex, Indonesia, Kalimantan Tengah: Barito Basin, $30 \mathrm{~km}$ west of Ampah; H. Kishi et al., April 2019; SJD KA 2101, 2ex, Indonesia, Kalimantan Tengah: Kahayan Basin, 25 km west of Palangkaraya; H. Kishi et al., April 2019;

Parosphromenus harveyi, SJD MA 2031, 1 male, Malaysia, Selangor: Batu Arang (type locality); A. Bakhtiar et al., October 2019;

Parosphromenus quindecim, Topotype: SJD KA 2011, 3 ex, Indonesia, Kalimantan Barat: Sungai Pawan Basin (type locality); Y. H. Ji, September, 2017;

Parosphromenus bintan, ZRC30815, 11 ex., 20.3-24.1 mm Indonesia, Bangka-Belitung: Bangka: 2 km east of Kampong Bilek; M. Kottelat et al., 4 March 1993 photographed in April. 2021;

Parosphromenus deissneri, ZRC 46184, 2 ex., 24.1-24.3 mm, Indonesia: Sumatra, 'Biliton', trade material, colls. T. Sim, Feb. 2000, photographed in Jan. 2021;

\section{Scientific field survey permission information}

Indonesia's field surveys were approved under the collaborative project between the School of Life Sciences, Nanchang University (China) and the Research Center for Biology, Indonesian Institute of Sciences (Indonesia), in-situ survey certificate (B-3627/IPH.1.02/KS.01.04/IX/2019), and the Non-Commercial Biological Material Transfer Agreement (No. B-1512/IPH.1/KS.01.04/XII/2020).

\section{Authors' Contributions}

W.C. ZHANG, W.T. SHI and Y.J. HONG conceived and designed the study. W.T. SHI and H. HARYONO collected specimens in the field. S.J. GUO and W.C. ZHANG performed the morphometric measurements, the DNA extraction, sequencing and molecular analysis. W.T. SHI and W.C. ZHANG wrote and revised the manuscript. All authors read and approved the final manuscript. 


\section{Competing interests}

The authors declare that they have no competing interests.

TABLE 1. Morphometric and meristic data of Parosphromenus juelinae sp. nov. ( $\mathrm{n}=15$, MZB 25116, MZB 25117 and NCUMB 65121) from Bangka Island and Parosphromenus kishii sp. nov. ( $\mathrm{n}=9$, MZB 25120, MZB 25121 and NCUMB 65135) from Kalimantan Tengah, Indonesia.

\begin{tabular}{|c|c|c|}
\hline & Parosphromenus juelinae & Parosphromenus kishii \\
\hline \multicolumn{3}{|l|}{ MORPHOMETRICS } \\
\hline Standard length $(\mathrm{mm})($ mean \pm SD $)$ & $12.3-19.5(16.8 \pm 2.1)$ & $12.2-31.4(15.6 \pm 6.0)$ \\
\hline \multicolumn{3}{|l|}{ In $\% \mathrm{SL}$} \\
\hline Total length & $111-132(125 \pm 4.9)$ & $117-135(126 \pm 5.8)$ \\
\hline Predorsal length & $35.0-46.3(38.4 \pm 2.9)$ & $31.8-38.6(36.0 \pm 1.9)$ \\
\hline Postdorsal length & $18.7-32.7(24.4 \pm 3.7)$ & $20.7-25.4(23.1 \pm 1.5)$ \\
\hline Preanal length & $37.8-66.0(48.8 \pm 7.6)$ & $40.9-63.7(47.6 \pm 6.5)$ \\
\hline Head length (HL) & $25.3-37.9(32.0 \pm 2.9)$ & $27.3-39.4(32.9 \pm 3.9)$ \\
\hline Body depth at dorsal-fin origin & $22.7-33.7(28.1 \pm 3.0)$ & $24.0-43.4(37.5 \pm 6.8)$ \\
\hline Pelvic-fin length & $18.8-46.1(31.3 \pm 2.9)$ & $26.4-32(29.2 \pm 2.0)$ \\
\hline Anal-fin base length & $45.2-56.1(51.0 \pm 3.3)$ & $37.9-50.0(47.7 \pm 3.8)$ \\
\hline Dorsal-fin base length & $29.5-46.1(37.7 \pm 4.2)$ & $37.1-41.8(39.6 \pm 1.6)$ \\
\hline Caudal peduncle depth & $7.9-14.0(12.2 \pm 1.5)$ & $10.4-20.0(14.6 \pm 3.2)$ \\
\hline \multicolumn{3}{|l|}{ In \% HL (mean) } \\
\hline Orbit diameter & $25.9-35.6(29.9 \pm 2.5)$ & $5.9-12.3(10.7 \pm 2.0)$ \\
\hline Postorbital length & $37.8-53.5(43.9 \pm 3.9)$ & $11.0-18.9(13.9 \pm 2.3)$ \\
\hline Interorbital distance & $25.8-34.9(30.4 \pm 2.6)$ & $11.5-19.7(16.9 \pm 2.4)$ \\
\hline Snout length & $22.2-31.0(26.7 \pm 2.3)$ & - \\
\hline \multicolumn{3}{|l|}{ MERISTICS (Total counts) } \\
\hline Anal-fin rays & X-XII, 9-10 (19-22, 21*) & XII-XIII, 9-10 (21-23, 22*) \\
\hline Dorsal-fin rays & XII-XIV, 6-7 (18-21, 19*) & XIII-XIV, 6-7 (20-22, 20*) \\
\hline Caudal-fin rays & iii, $5+6$, ii & iii, $5+6$, ii \\
\hline Pelvic-fin rays & $\mathrm{I}, 1,4$ & $\mathrm{I}, 1,4$ \\
\hline Pectoral-fin rays & $12-14\left(14^{*}\right)$ & $12-14(13 *)$ \\
\hline Lateral scales & $29-30(30 *)$ & $29-30(30 *)$ \\
\hline Transverse scales from $4^{\text {th }}$ anal-fin spine & $9-10\left(10^{*}\right)$ & $9(9 *)$ \\
\hline Transverse scales at dorsal-fin origin & $11-12(11 *)$ & $11(11 *)$ \\
\hline
\end{tabular}

\section{Acknowledgements}

Most of the material used in this study was obtained during fieldwork carried out and donated by Jian Hui Dai and Yu Han Ji. Horst Linke and Peter Finke provided guidance and encouragement over the years. Tan Heok Hui helped to improve the manuscript critically and provided images and information about the specimens deposited at the Lee Kong Chian Natural History Museum. An anonymous reviewer provided constructive comments concerning the molecular analysis section. Lukas Rüber and Jörg Freyhof contributed enlightening discussion about the phylogenetic issues and methods of molecular analysis. Stepan Lang and Ulrich Schlösser helped in general academic preparation of the manuscript. The Parosphromenus-Project supported the survey, conservation and studies on this genus, Bin Sun, Hendry Sutrisno, Hermanus Haryanto and Oktavianus J. Bangun provided field assistance and logistic support. David Armitage and Travonim contributed information about the survey and specimens in Bangka Belitung. The project was funded by the Jiangxi Agricultural Research System (JXARS-10) and the Natural Science Foundation of Jiangxi Province (2020BAB215012). 


\section{Ethic statement}

Samples collected from filed surveys were preserved in $95 \%$ ethanol for laboratory works. All experimental procedures were in accordance with the guidelines and approved by the Animal Care and Use Committee of Nanchang University.

\section{Amplification, sequencing and phylogenetic analyses}

Molecular analyses: Total genomic DNA was isolated from muscle tissues of examined samples preserved in 95\% ethanol using the TIANamp Marine Animals DNA kit (Tiangen, China). Sequences encoding the mitochondrial gene cytochrome $b$ was amplified using the primers of Rüber et al. (2004). The sequences of the primers are DonGlu-F (5'-AACCACCGTTGTATTCAACTACAA-3') and DonThr-R (5'-ACCTCCGATCTTCGGATTACAAGACCG3 '), encoding a product of $\sim 1,080 \mathrm{bp}$. We amplified the whole sequence of the cytb gene in the 31 specimens, which was subsequently sequenced for Sanger sequencing. The whole sequence of $c y t b$ for each individual was obtained by assembling the sequenced products using ContigExpress (http://www.contigexpress.com).

Phylogenetic analyses: We employed the MEGA X (Kumar et al., 2018) to construct the genealogical relationships in Parosphromenus. Neighbor-joining (NJ) and maximum-likelihood (ML) methods were adopted to examine the topology consistency. For ML-tree, we first tested the optimal model using the alignment of the 31 specimens. Tamura-Nei model scored the best and then used to construct the ML tree. Kimura 2-parameter model was used to build the NJ-tree. Pair-wise genetic distances (uncorrected $P$-distances) between species and K2P intraspecies distance were calculated. Bootstrap support was performed for 1000 times. Both the NJ-tree and ML-tree indicate a highly concordant topology structure of the genus Parosphromenus, which suggests a convincing phylogenic relation among the species. The intraspecies genetic divergence of the Parosphromenus is less than $0.27 \%$, which is significantly lower than the interspecies divergence $(2.44 \%$ to $19.52 \%)$. These results indicate that the current taxonomic system of this genus and our diagnoses of the two new species are valid.

\section{Comparative material examined: Notes}

In our examination we noticed that the specimens of these two series ZRC30815 and ZRC 46184 are morphologically closer to Parosphromenus juelinae instead of $P$. bintan or $P$. deissneri.

- ZRC30815 (Fig. S3): In these specimens a row of interrupted hyaline spots is present in the caudal fin. This morphological trait is inconsistent with all other specimens of the type series of $P$. bintan and the topotypes obtained from its type locality in 2021 (Fig. S2), which all have a continuous hyaline band in caudal fin. In contrary they are morphologically highly similar to $P$. juelinae, and the collecting location of these specimens are only a few kilometers away from the type locality of $P$. juelinae. We tend to consider that these specimens might be $P$. juelinae instead of $P$. bintan. Further field survey and fresh specimens from this location is required to clarify this issue.

- ZRC 46184 (Fig. S4): In these specimens the median rays of the caudal fin are branched instead of simple; no filament can be recognized; caudal fin shape is rounded and the margin of the fin around the median ray is smooth without damage, which suggests that the absence of filament is not due to damage. Thus, they are not P. deissneri. This is consistent with the previous reports (Armitage 2002, Linke 2014, Kishi et al. pers. comm. 2012) and our recent field survey results, that $P$. deissneri is not distributed in Belitung Island. However, the commercial label of collecting location 'Biliton' conflicts with our field survey results. We have never recorded $P$. juelinae in Belitung, and the streams of the new species in Bangka run towards the north coast of Bangka, which is the opposite direction towards Belitung Island. Meanwhile, during our survey in 2019 we met a local fisherman near the habitat of $P$. juelinae who had collected this species around twenty years ago for a fish trader from Sumatra called 'Simo' or 'Sin'; And the two specimens in Singapore coincidentally came from a supplier based in Sumatra Island with the name Sim in a similar time window. Considering all these facts, we tend to consider that these two specimens were just $P$. juelinae caught from Bangka, since mislabel of location 
is a common phenomenon in the business of ornamental fish trading to protect commercial secrets. Thus, based on current field data, $P$. juelinae is still considered to be endemic in Bangka Island. However, considering this problematic location data of the two specimens, they are not included in the Paratype series but listed as comparative materials.

\section{References}

Armitage, D. (2002) Bettas \& Co. von Bangka und Belitung. Das Aquarium, 397, 10-15.

Bleeker, P. (1859) Negende bijdrage tot de kennis der vischfauna van Banka. Natuurkundig Tijdschrift voor Nederlandsch Indië, 18, 359-378. https://doi.org/10.5962/bhl.title.144153

Brown, B. (1987) Special announcement-two new Anabantoid species. Aquarist and Pondkeeper, 1987, 34.

Cracraft, J. (1989) Speciation and Its Ontology: The Empirical Consequences of Alternative Species Concepts for Understanding Patterns and Processes of Differentiation. In: Daniel, O. \& John, A.E. (Eds.), Speciation and Its Consequences, Sinauer, Sunderland, Massachusetts, pp. 28-59.

Klausewitz, W. (1955) See- und Süsswasserfische von Sumatra und Java. Senckenbergiana Biologica, 36, 309-323.

Kottelat, M. (1991) Notes on the taxonomy and distribution of some western Indonesian freshwater fishes, with diagnoses of a new genus and six new species (Pisces: Cyprinidae, Belontiidae, and Chaudhuriidae). Ichthyological Exploration of Freshwaters, 2 (3), 273-287.

Kottelat, M. \& Ng, P.K.L. (1998) Parosphromenus bintan, a new osphronemid fish from Bintan and Bangka islands, Indonesia, with redescription of P. deissneri. Ichthyological Exploration of Freshwaters, 8 (3), 263-272.

Kottelat, M. \& Ng, P.K.L. (2005) Diagnoses of six new species of Parosphromenus (Teleostei: Osphronemidae) from Malay Peninsula and Borneo, with notes on other species. Raffles Bulletin of Zoology, Supplement 13, 101-113.

Kumar, S., Stecher, G., Li, M., Knyaz, C. \& Tamura, K. (2018) MEGA X: Molecular Evolutionary Genetics Analysis across computing platforms. Molecular Biology and Evolution, 35, 1547-1549. https://doi.org/10.1093/molbev/msy096

Linke, H. (2014) Labyrinth Fish World with 1768 selected photographs. Fish Magazine Taiwan, New Taipei City, 577 pp.

Mayden R.L. \& Wood R.M. (1995) Systematics, species concepts, and the evolutionarily significant unit in biodiversity and conservation biology. American Fisheries Society Symposium, 17, 58-113.

Rüber, L., Britz, L., Tan, H.H., Ng, P.K.L. \& Zardoyz, R. (2004) Evolution of Mouthbrooding and Life-history correlates in the fighting fish genus Betta. Evolution, 58, 799-813. https://doi.org/10.1111/j.0014-3820.2004.tb00413.x

Schaller, D. (1985) Parosphromenus nagyi spec. nov., ein neuer Prachtgurami aus Malaysia (vorläufige Mitteilung). Die Aquarien- und Terrarien-Zeitschrift, 38, 301-303.

Schindler, I. \& Linke, H. (2012) Two new species of the genus Parosphromenus (Teleostei: Osphronemidae) from Sumatra. Vertebrate Zoology, 62 (3), 399-406.

Tan, H.H. \& Ng, P.K.L. (2005) The labyrinth fishes (Teleostei: Anabantoidei, Channoidei) of Sumatra, Indonesia. Raffles Bulletin Zoology, Supplement 13, 115-138.

Tan, H.H. \& Jongkar, G. (2020) Parosphromenus barbarae, a new species of Licorice Gourami from Sarawak, Borneo (Teleostei: Osphronemidae). Vertebrate Zoology, 70 (3), 349-356. https://doi.org/10.26049/VZ70-3-2020-07

Turner, G.F. (1999) What is a fish species? Reviews in Fish Biology and Fisheries, 9, 281-297. https://doi.org/10.1023/A:1008903228512

Tweedie, M. (1952) Notes on Malayan fresh-water fishes. 3, The Anabantoid fishes; 4, New and interesting records; 5, Malay names. Bulletin of the Raffles Museum, 24, 63-95.

Vierke, J. (1979) Ein neuer Labyrinthfisch von Borneo—Parosphromenus parvulus nov. spec. Das Aquarium, 13 (120), 247250.

Vierke, J. (1981) Parosphromenus filamentosus n. sp. aus SO Borneo (Pisces: Belontiidae). Senckenbergiana Biologica, 61, 363-367.

Warren, M.L. (1992) Variation of the spotted sunfish, Lepomis punctatus complex (Centrarchidae): meristics, morphometrics, pigmentation and species limits. Bulletin of the Alabama Museum of Natural History, 12, 1-47.

Zhou, A.G., Xie, S., Wang, Z., Fan, L., Chen, Y., Ye, Q., Zeng, F. \& Zou, J. (2019) Genetic diversity and geographic differentiation in Northern Snakehead (Channa argus) based on mitochondrial Cytb gene. Pakistan Journal of Zoology, 51 (1), 359-362.

https://doi.org/10.17582/journal.pjz/2019.51.1.sc2 
SUPPLEMENTARY FIGURE S1. Parosphromenus deissneri, ZRC31017 18.2-23.2 mm, Banka, M. Kottelat et al., 3 March 1993, (photograph: Tan H. H. in 19. Apr. 2021);

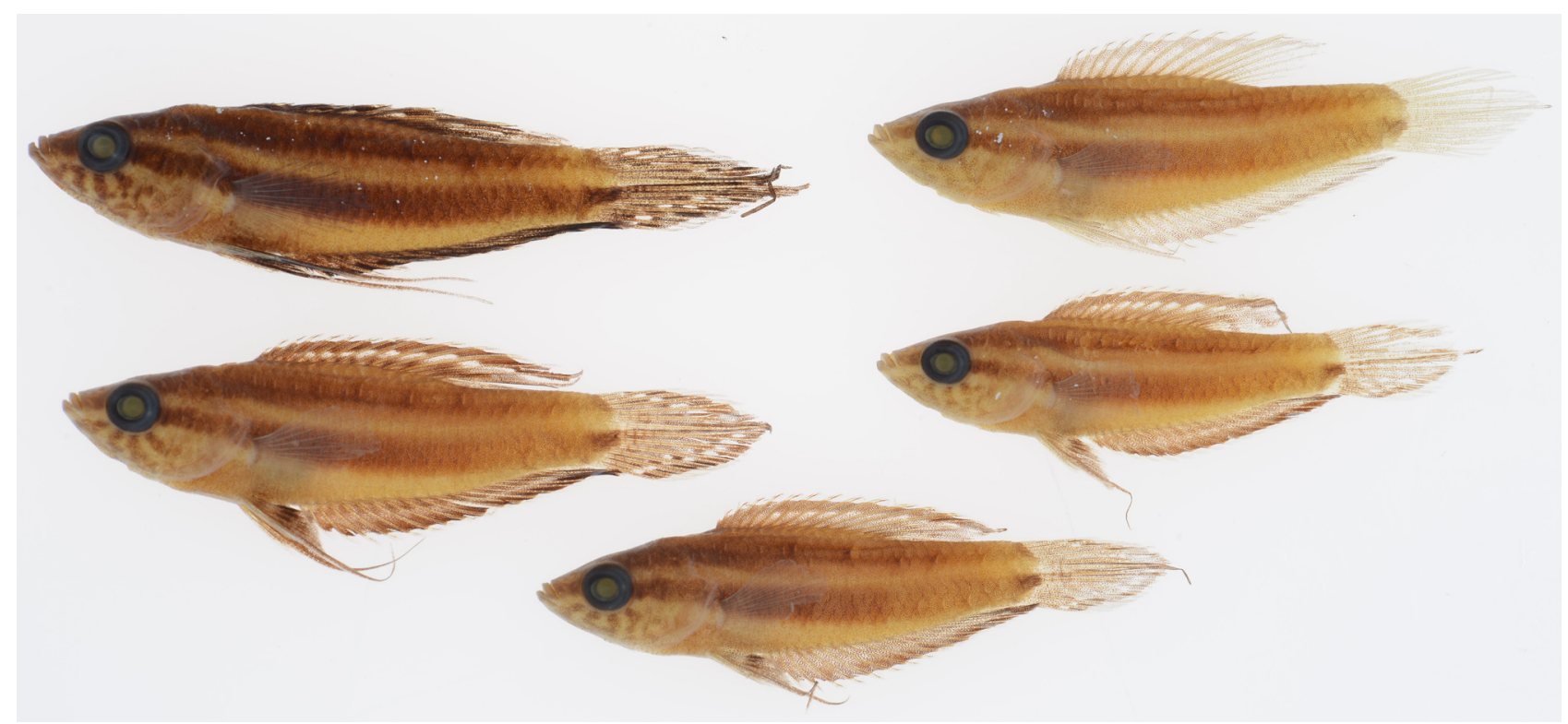


SUPPLEMENTARY FIGURE S2. (A). Parosphromenus bintan, Paratype: ZRC41403 24.0 mm, Bintan Island, photographed in Jan. 2021 on black background; (B) same specimens ZRC41403 on white background (photograph: Tan H. H.); (C). Topotype: SJD BI 2011, 1 male, same data as Holotype, Indonesia, Riau: Bintan Island; O. J. Bangun, March 2021.
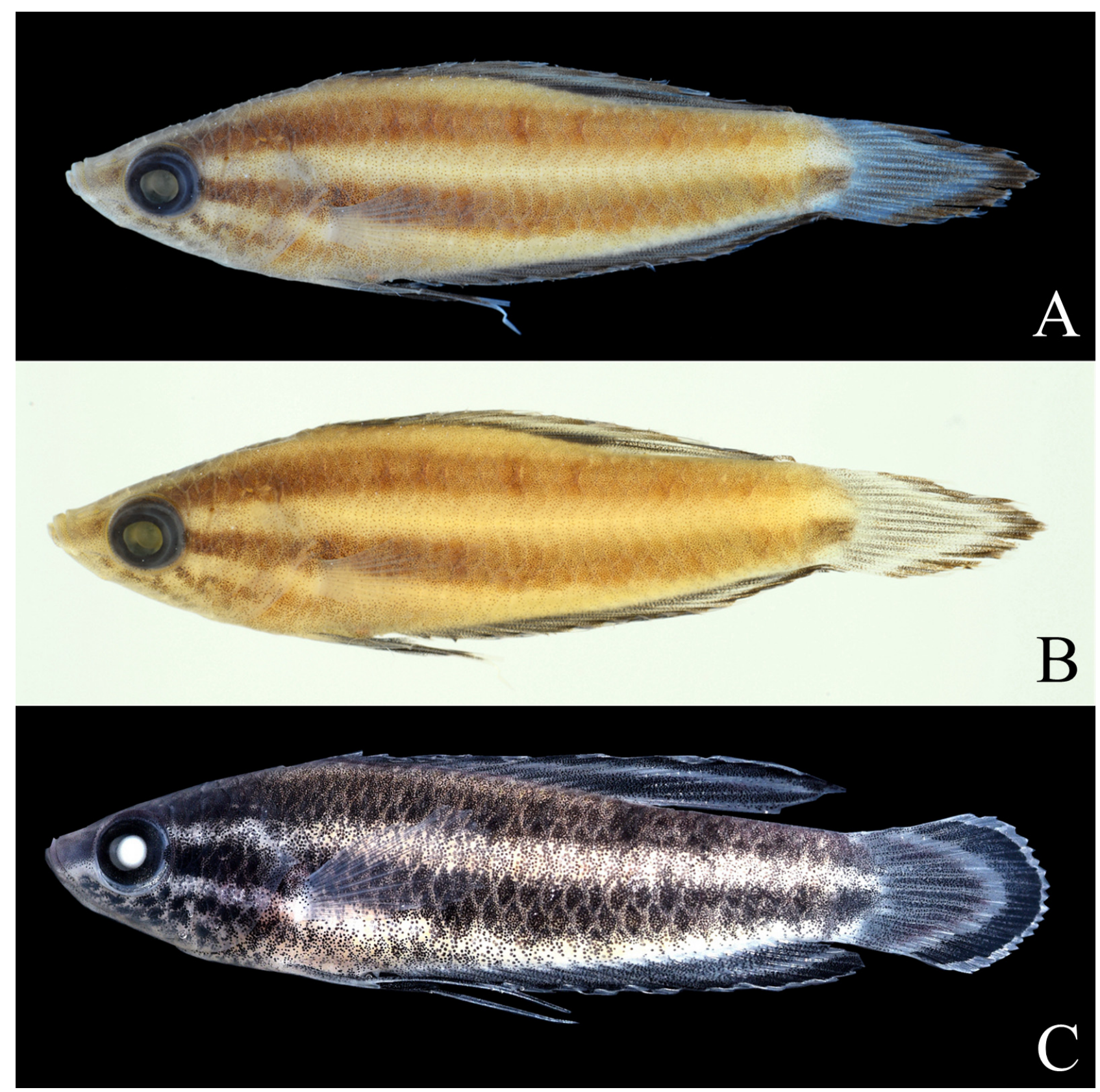
SUPPLEMENTARY FIGURE S3. Parosphromenus bintan, ZRC30815, 11 ex., 20.3-24.1 mm Indonesia, Bangka-Belitung: Bangka: 2 km east of Kampong Bilek; M. Kottelat et al., 4 March 1993 (photograph: Tan H. H., 19. Apr. 2021)

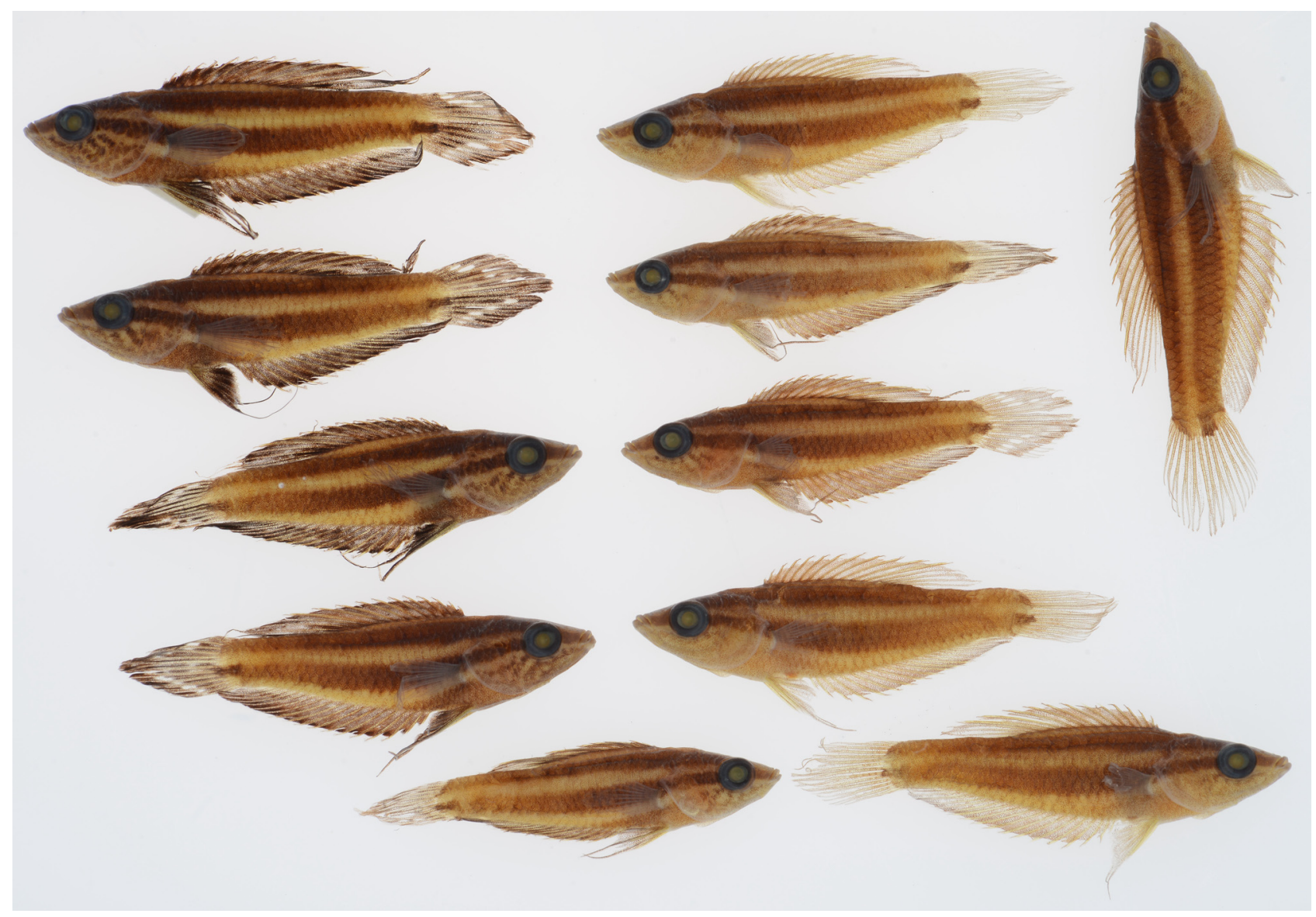


SUPPLEMENTARY FIGURE S4. (A) Parosphromenus juelinae, ZRC 46184, $24.3 \mathrm{~mm}$ SL, male, Indonesia: Sumatra, 'Biliton', trade material; colls. T. Sim, Feb 2000, photographed on black background (right-side reversed). (Photograph: Tan H. H., 26. Jan. 2021); (B) same specimens ZRC 46184, male, photographed on white background (right-side reversed); (C) Parosphromenus juelinae, ZRC 46184, 24.1 mm SL, female, Indonesia: Sumatra, 'Biliton', trade material; colls. T. Sim, Feb 2000, photographed on black background (photograph: Tan H. H., 26. Jan. 2021); (D) same specimens ZRC 46184, female, photographed on white background.
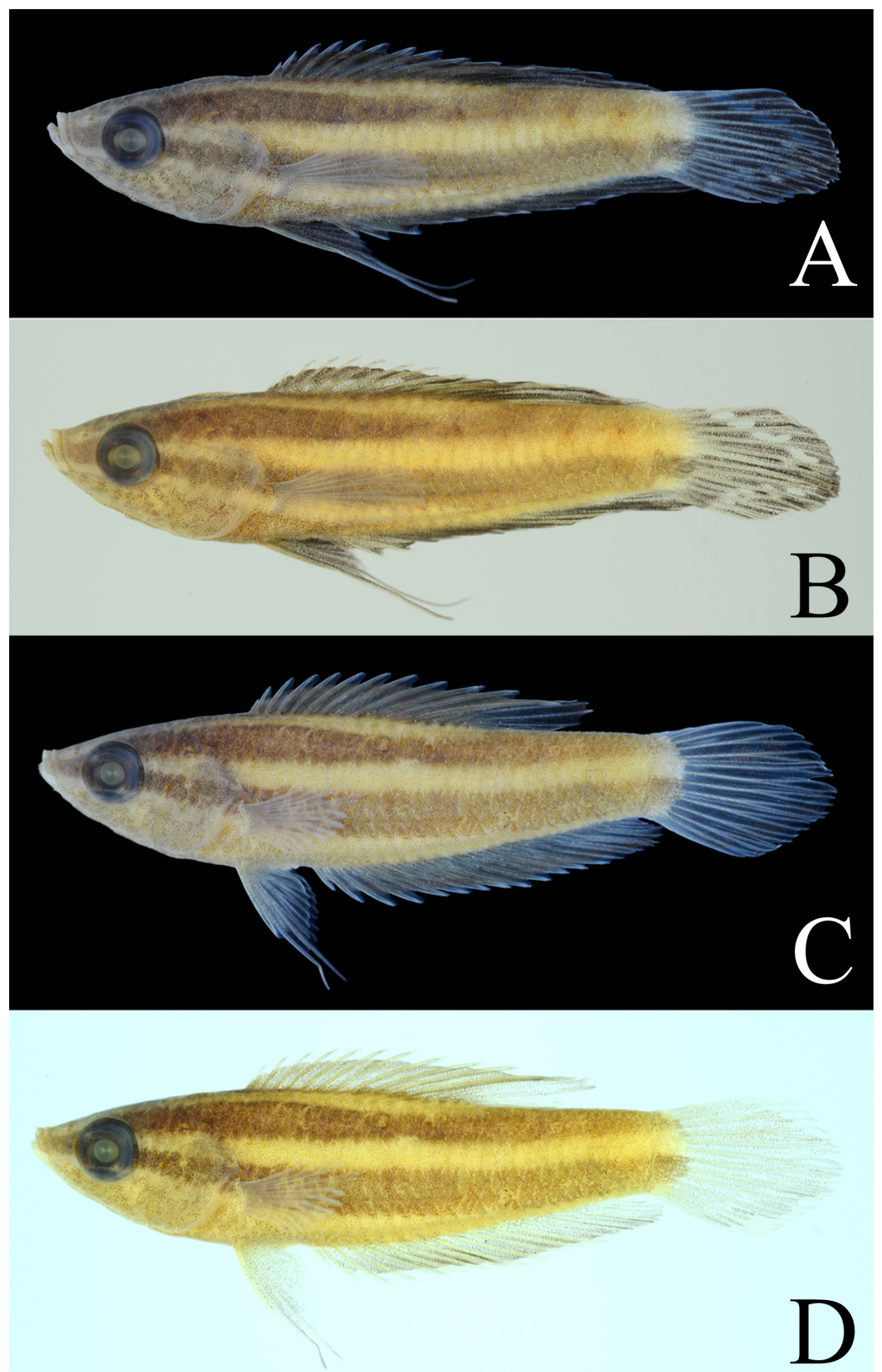
SUPPLEMENTARY TABLE S1. Detailed information of Parosphromenus species and outgroup used in the present study

\begin{tabular}{|c|c|c|c|}
\hline Species & $\begin{array}{l}\text { Accession } \\
\text { number }\end{array}$ & Sample site & Origin \\
\hline Parosphromenus parvulus & MZ578470 & $\begin{array}{l}\text { Sungai Kahayan Basin, Kalimantan } \\
\text { Tengah }\end{array}$ & $\begin{array}{l}\text { trade material from Bin } \\
\text { Sun, } 2018\end{array}$ \\
\hline Parosphromenus quindecim & MZ578479 & Type locality, Kalimantan Barat & Yuhan Ji, 2017 \\
\hline Parosphromenus kishii sp. nov. & MZ578480 & Type locality, Kalimantan Tengah & Hiroyuki Kishi, 2019 \\
\hline Parosphromenus kishii sp. nov. & MZ578481 & Type locality, Kalimantan Tengah & Hiroyuki Kishi, 2019 \\
\hline Parosphromenus kishii sp. nov. & MZ578482 & Type locality, Kalimantan Tengah & Hiroyuki Kishi, 2019 \\
\hline Parosphromenus kishii sp. nov. & MZ578483 & Type locality, Kalimantan Tengah & Hiroyuki Kishi, 2019 \\
\hline Parosphromenus kishii sp. nov. & MZ578484 & Type locality, Kalimantan Tengah & Hiroyuki Kishi, 2019 \\
\hline Parosphromenus filamentosus & MZ578485 & $\begin{array}{l}\text { Sungai Barito Basin, Kalimantan } \\
\text { Tengah }\end{array}$ & Hiroyuki Kishi, 2019 \\
\hline Parosphromenus filamentosus & MZ578486 & $\begin{array}{l}\text { Sungai Barito Basin, Kalimantan } \\
\text { Tengah }\end{array}$ & Hiroyuki Kishi, 2019 \\
\hline Parosphromenus filamentosus & MZ578487 & $\begin{array}{l}\text { Sungai Barito Basin, Kalimantan } \\
\text { Tengah }\end{array}$ & Hiroyuki Kishi, 2019 \\
\hline Parosphromenus juelinae sp. nov. & MZ578488 & Type locality, Bangka Island & Jianhui Dai, 2019 \\
\hline Parosphromenus juelinae sp. nov. & MZ578489 & Type locality, Bangka Island & Jianhui Dai, 2019 \\
\hline Parosphromenus juelinae sp. nov. & MZ578490 & Type locality, Bangka Island & Jianhui Dai, 2019 \\
\hline Parosphromenus juelinae sp. nov. & MZ578491 & Type locality, Bangka Island & Jianhui Dai, 2019 \\
\hline Parosphromenus juelinae sp. nov. & MZ578492 & Type locality, Bangka Island & Jianhui Dai, 2019 \\
\hline Parosphromenus deissneri & MZ578493 & $\begin{array}{l}\text { Near collection location of neotype, } \\
\text { Bangka Island }\end{array}$ & Yuhan Ji, 2017 \\
\hline Parosphromenus deissneri & MZ578494 & $\begin{array}{l}\text { Near collection location of neotype, } \\
\text { Bangka Island }\end{array}$ & Yuhan Ji, 2017 \\
\hline Parosphromenus deissneri & MZ578495 & Bangka Island & $\begin{array}{l}\text { trade materials from Hendry } \\
\text { Sutrisno } 2021\end{array}$ \\
\hline Parosphromenus deissneri & MZ578496 & Bangka Island & $\begin{array}{l}\text { trade materials from Hendry } \\
\text { Sutrisno } 2021\end{array}$ \\
\hline Parosphromenus harveyi & MZ578497 & Type locality, Batu Arang, Malaysia & $\begin{array}{l}\text { trade materials from Adam } \\
\text { Bakhtiar } 2019\end{array}$ \\
\hline Parosphromenus harveyi & MZ578498 & Type locality, Batu Arang, Malaysia & $\begin{array}{l}\text { trade materials from Adam } \\
\text { Bakhtiar } 2019\end{array}$ \\
\hline Parosphromenus sp. Tangkit & MZ578499 & Tangkit, Jambi & $\begin{array}{l}\text { trade materials from Ahmad } \\
\text { Maliki, } 2021\end{array}$ \\
\hline Parosphromenus cf. bintan & MZ578500 & Sijok, Belitung Barat & Jianhui Dai, 2018 \\
\hline Parosphromenus cf. gunawani & MZ578471 & Jambi, Sumatra & $\begin{array}{l}\text { trade materials from Hendry } \\
\text { Sutrisno } 2021\end{array}$ \\
\hline Parosphromenus cf. gunawani & MZ578472 & Jambi, Sumatra & $\begin{array}{l}\text { trade materials from Hendry } \\
\text { Sutrisno } 2021\end{array}$ \\
\hline Parosphromenus bintan & MZ578473 & Bangka & $\begin{array}{l}\text { trade materials from Hendry } \\
\text { Sutrisno } 2021\end{array}$ \\
\hline Parosphromenus bintan & MZ578474 & Bangka & $\begin{array}{l}\text { trade materials from Hendry } \\
\text { Sutrisno } 2021\end{array}$ \\
\hline
\end{tabular}


SUPPLEMENTARY TABLE S1. (Continued)

\begin{tabular}{llll}
\hline Species & $\begin{array}{l}\text { Accession } \\
\text { number }\end{array}$ & Sample site & Origin \\
\hline Parosphromenus bintan & MZ578475 & Bangka & $\begin{array}{l}\text { trade materials from Hendry } \\
\text { Sutrisno 2021 }\end{array}$ \\
Parosphromenus bintan & MZ578476 & $\begin{array}{l}\text { Sungai Kotawaringin Basin, Bangka } \\
\text { (south of Paratype series ZRC 31327) }\end{array}$ & Jianhui Dai, 2018 \\
Parosphromenus bintan & MZ578477 & $\begin{array}{l}\text { Sungai Kotawaringin Basin, Bangka } \\
\text { (south of Paratype series ZRC 31327) }\end{array}$ & Jianhui Dai, 2018 \\
Parosphromenus bintan & MZ578478 & Bangka & trade materials from Hendry \\
Sphaerichthys osphromenoides & MZ578469 & $\begin{array}{l}\text { Type locality of Parosphromenus } \\
\text { juelinae } \text { sp. nov., Bangka }\end{array}$ & Jianhui Dai, 2018 \\
\hline
\end{tabular}




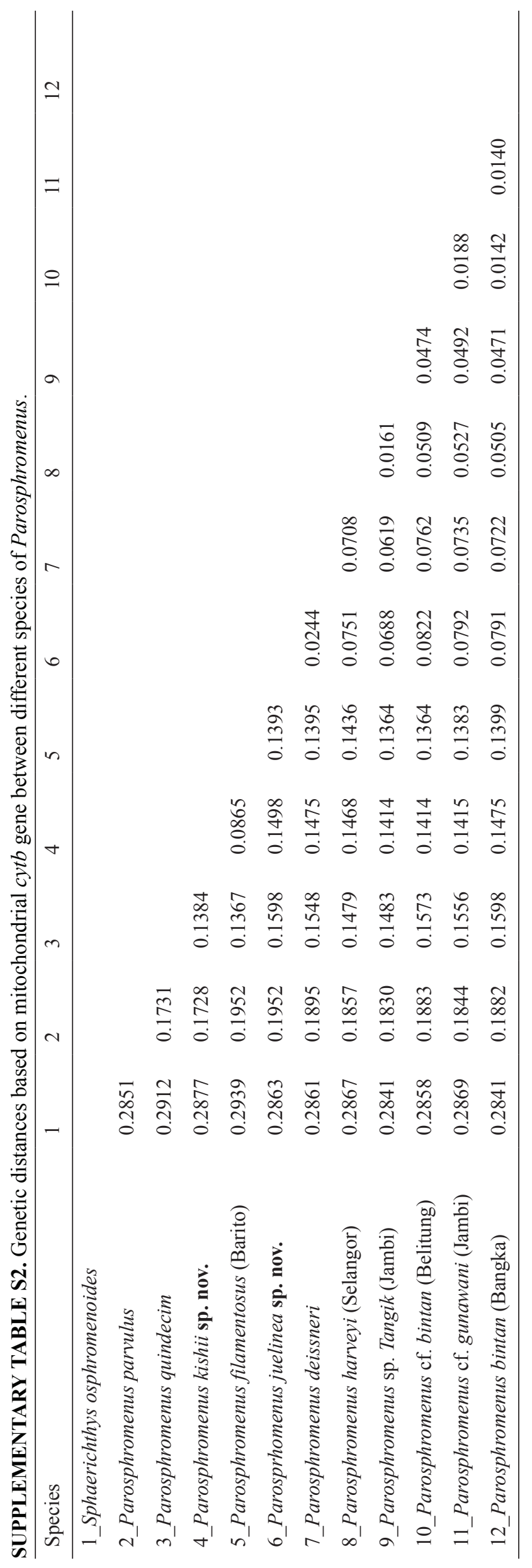

